\title{
RELASI ANTARA SENI DENGAN TEOLOGI KRISTEN
}

\author{
Yunatan Krisno Utomo
}

(Dosen Musik Gereja: yunatan.utomo@gmail.com)

\begin{abstract}
Art is often viewed as a worldly thing connected with worldly luxuries and pleasures. In response to the use of this art, it is no wonder that among mainstream theologians there is a dichotomy between the spiritual and the earthly or the holy and the secular. The effect is that many Christians close themselves to the things they regard as 'worldly' in the social life of society, and they live alone isolated in their holiness. This study discusses that art is God's creation, so the presence of art should be able to help humanity establish its existence as a creature and be able to help human beings become closer to God.
\end{abstract}

\section{E. PENDAhuluan}

Seni sering dihubungkan dengan hal-hal yang bersifat duniawi, kesenangan duniawi, dan kehidupan hedonis yang cenderung menjerat manusia menuju lembah kekelaman, jauh dari Tuhan. Dengan kata lain, seni dipandang sebagai hal jasmani berlawanan dengan hal-hal rohani dalam teologi Kristen. Itu sebabnya tidak banyak teolog yang sungguh-sungguh tertarik mengembangkan seni untuk teologinya. Begbie mengatakan "There must be few theologians of this century for whom art has been more important than Paul Tillich (1886-1965)." Pernyataan Begbie ini mengkonfirmasi bahwa tidak banyak teolog yang konsen dengan pemakaian seni dalam mengembangkan teologinya atau memaknai seni sebagai sesuatu yang sangat berharga dan bermakna yang dapat menyegarkan jiwa, dan juga memandang seni sebagai sumber yang luar biasa dalam menstimulus intelektual. Malahan justru muncul kekuatiran dan ketakutan dari teolog-teolog tertentu terhadap pemakaian seni itu. Rookmaaker, seorang dari kelompok teolog Reformed berpendapat bahwa kaum Puritan terperosok dalam mistisisme kesalehan yang menyangkali kenikmatan dari seni visual karena prioritas mereka pada penyembuhan rohani. ${ }^{2}$ Mereka memandang kekudusan secara subjektif dan menjauhkan diri dari seni yang bagus dengan menggolongkannya sebagai keduniawian.

Masih sangat terasa adanya dikotomi antara yang rohani dan duniawi atau yang kudus dan sekuler, yang pada akhirnya berimplikasi pada semakin banyaknya orang-orang Kristen yang menutup diri dan mata terhadap hal-hal yang dipandangnya sebagai 'duniawi' di dalam kehidupan sosial masyarakat, dan mereka hidup sendiri terisolasi di dalam kekudusannya. Seni dinilai sebagai hal yang duniawi (tidak kudus), sehingga dapat mengotori jiwa, kehidupan rohani maupun teologi. Fenomena seni yang terhubung dengan dunia hiburan memang membuktikan keberadaan seni yang tidak pernah jauh dari pesta kesenangan, hura-hura dan kepuasan manusia. Namun benarkah bahwa seni yang kaya dengan ragam dan jenis itu semuanya tercakup dalam fungsi hiburan saja? Apakah bidang lain seperti pendidikan dan teologi tidak dapat mengambil manfaat dari seni tersebut? Kalau seni merupakan ciptaan Tuhan untuk kehidupan manusia, tentu kehadiran seni seharusnya dapat menolong manusia membangun keberadaannya sebagai makhluk ciptaan yang bertumbuh menuju kedewasaan dan \footnotetext{
Clark, 2006), 1. 2017), 49 .

${ }^{2}$ David W. Hall \& Marvin Padgett (Ed.), Calvin dan Kebudayaan (Surabaya: Momentum,
}

${ }^{1}$ Jeremy S. Begbie, Voicing Creation's Towards A Theology of The Arts (New York: T \& T. 
keserupaan dengan Allah. Lebih lanjut, Allah menciptakan dunia dan isinya (termasuk seni) adalah demi kemuliaan Allah dan bukan demi kepentingan dan kepuasan dari manusia itu sendiri. Maka seharusnya seni dapat dipakai sebagai sarana untuk manusia semakin dekat dengan Allah dan bukan sebaliknya.

Tulisan ini bertujuan untuk menjelaskan bagaimana hubungan seni dan teologi Kristen. Penulis memiliki keyakinan bahwa, seni dapat dipakai sebagai media untuk memperkaya dan memajukan teologi Kristen, baik melalui unsur simbolik, estetis, kreatif, inovatif maupun unsur gagasan yang hendak disampaikan melalui seni tersebut. Penulis percaya bahwa seni adalah ciptaan Tuhan, sehingga keberadaannya seharusnya dapat dipergunakan untuk memuliakan Tuhan, dan bukan untuk memuliakan manusia. Seni dapat dipergunakan sebagai media untuk memperkuat pendidikan moralitas maupun spiritualitas apabila diintegrasikan dan dijiwai oleh teologi Kristen yang benar. Seni seharusnya dijadikan sebagai mitra dari teologi dan bukan sebagai musuh yang sengaja dipertentangkan. Seni seharusnya menjadi media untuk membangun harmoni di antara ciptaan Allah, dan tidak seharusnya menjadi sumber konflik di antara manusia, seperti yang sering terjadi di antara para teolog maupun di antara gereja satu dengan lainnya. ${ }^{3}$

\section{F. METODOLOGI}

Penelitian ini menggunakan metode penelitian kualitatif melalui studi pustaka dengan pendekatan teologis. Sumber data yang digunakan meliputi buku-buku literatur dan jurnal-jurnal penelitian yang membahas tentang seni, musik dan teologi. Teknik analisis data dilakukan dengan tahapan yang disarankan oleh Miles dan Huberman, yang meliputi reduksi data, mengklasifikasi, mengintepretasi dan memaparkan data dalam bentuk deskripsi dan analisis. ${ }^{4}$ Proses analisis dan tahap verifikasi dilakukan peneliti melalui analisis teoretik, mendiskusikannya dengan teori-teori yang relevan dan menafsirkannya untuk menggali dan menunjukkan makna penting yang terkandung di dalamnya. ${ }^{5}$

\section{G. PEMBAHASAN}

1. Apakah Seni itu?

Seni merupakan salah satu bagian dari kebudayaan manusia, yaitu sebagai unsur kebudayaan yang kaya dengan cita rasa keindahan. Seni dapat mengekspresikan pesan secara mendalam, terdiri dari beberapa ragam, seperti: musik atau nyanyian, drama, film, sastra, tarian, lukisan, animasi, dekorasi, pahatan, patung, ukiran, kerajinan tangan, seni bangunan (arsitektur) dan lainnya. Ragam seni tersebut pada dasarnya memiliki karakteristik dan prinsip yang sama, namun memiliki wujud yang berbeda sebab tersusun atas materi dasar yang berbeda. Musik memiliki komponen dasar melodi, irama dan harmoni; tari tersusun atas elemen-elemen gerak tubuh, lukisan terdiri atas elemen-elemen garis, lengkung dan goresan yang lain; seni bangunan

13.

${ }^{3}$ Donald P. Hustad, Jubilate II: Church Music in Worship and Renewal (IL: Hope P.C. 1993),

${ }^{4}$ M. B. Miles, \& Huberman, A. M., Qualitative Data Analysis: An Expanded Sourcebook. Thousand Oaks, CA: Sage Publications, 1994.

${ }^{5}$ J. Cresswell, Riset Pendidikan: Perencanaan, Pelaksanaan, dan Evaluasi Riset Kuantitatif \& Kualitatif. Yogyakarta: Pustaka Pelajar, 2015. 
tersusun atas elemen sudut, ruang, lekuk yang semuanya diorganisasi secara indah dan harmonis.

Di masa kini seni telah terintegrasi secara meluas dan meresap dalam berbagai aspek kehidupan manusia, sehingga muncul istilah-istilah seni dalam berbagai bidang kehidupan masyarakat. Seni yang dihubungkan dengan teknik berkhotbah disebut seni berkhotbah, seni yang dihubungkan dengan teknik mengajar disebut seni mengajar, seni yang dihubungkan dengan cara berpakaian disebut seni berpakaian, seni yang dihubungkan dengan cara berkomunikasi disebut seni berkomunikasi, seni yang dihubungkan dengan teknik memimpin disebut seni memimpin, seni yang dihubungkan dengan bela diri disebut seni bela diri dan masih banyak lagi istilah-istilah semacam itu, bahkan seni juga sering dihubungkan dengan bidang ekonomi dan dunia usaha, sehingga muncul istilah seni usaha atau seni berbisnis. Dalam berbagai hal tersebut, seni nampaknya dipergunakan untuk memaksimalkan pencapaian dari tujuan dari bidang-bidang itu melalui kreasi, inovasi dan eksplorasi keindahan dari seni.

Rasa keindahan, ekspresi dan kreativitas merupakan karakteristik dasar yang melekat pada sebuah seni, dan menjadi daya pesona yang mampu menarik fokus perhatian banyak orang. Keindahan sendiri adalah nilai tambah yang dimiliki oleh seni, yang mampu mengambil fokus manusia, atau mengarahkan mata dan hati manusia kepada benda seni tersebut. Kemampuan seorang seniman mengolah atau mengorganisasi daya estetis, rasa hati, ekspresi jiwa dan harmoni elemen seni secara kreatif dan inovatif sangat penting dalam memaksimalkan komposisi sebuah seni. Daya itu pula yang dipakai orang-orang untuk mengintegrasikan seni ke dalam berbagai bidang lain, seperti misalnya bidang bisnis, bidang pendidikan maupun teologi Kristen.

Dalam buku Introduction to Aesthetics yang diterbitkan di London pada tahun 1949 oleh Prof. E.F. Carritt, ${ }^{6}$ lebih dari 40 representasi estetik kuno dan modern untuk menggambarkan ekspresi seni pada semua zaman, bahwa seni sebagai proses kreatif merupakan ekspresi rasa hati (mood), perasaan atau jiwa. Hal tersebut bermuara pada munculnya pengertian seni sebagai sarana berekspresi di dalam berbagai bidang. Apabila dikaitkan dengan teologi ibadah Kristen, maka panggilan yang diberikan Allah kepada umat-Nya untuk beribadah itu disambut oleh umat-Nya dengan jiwa manusia yang diekspresikan kepada Allah melalui seni.

Filsuf Schelling berpendapat bahwa, kemampuan manusia dalam membentuk simbol (seni) bersumber dari imajinasi Ilahi, yang menjembatani sesuatu yang riil dan yang ideal. ${ }^{7}$ Lebih lanjut dikatakan bahwa, sebagaimana alam semesta merupakan karya kreativitas imajinasi Tuhan, maka seni yang digubah manusia juga merupakan karya kreatif yang bersumber dari imajinasinya. Ini menjelaskan bahwa seni merupakan pemberian Allah, yang semestinya dapat dipergunakan untuk membangun relasi doa yang riil dan ideal, dan mampu menyemangati kedekatan manusia dengan Allah. Dalam seni terdapat nilai-nilai kebaikan yang dari Allah, yang dapat menginspirasi dan mengubah manusia. Filsuf Schelling menegaskan bahwa, seni dapat digunakan untuk menampilkan kebenaran yang lebih daripada filsafat; imajinasi lebih unggul dibanding intelek atau akal. ${ }^{8}$ Kalau ilmu pengetahuan lebih berdampak pada pembangunan teknologi yang digunakan manusia, maka seni lebih berdampak pada pembangunan

${ }^{6}$ Buku yang berjudul An Introduction to Aesthetics ini diterbitkan pertama kali tahun 1949, memperkenalkan tentang apa itu "aesthetics" dan persoalan-persoalan yang ada di dalamnya yang tidak hanya terkait dengan pengalaman keindahan saja, tetapi juga terkait dengan aspek filosofi dari seni itu sendiri, E. F. Carritt, An Introduction to Aesthetics (London: Routledge, 1949).

${ }^{7}$ Bambang Sugiharto (Ed.), Untuk Apa Seni (Bandung: Matahari, 2013), 24.

${ }^{8}$ Gian N. G. Orsini, Benedetto Croce: Philosopher of Art and Literary Critic (Carbondale, III, 1961), 46-63. Lihat juga: Bambang Sugiharto, editor., Untuk Apa Seni (Bandung: Matahari, 2013 ), 24. 
manusianya. Artinya ada sesuatu keterbatasan akal manusia, yang dapat dilewati oleh seni. Ada yang tidak dapat dijelaskan oleh akal dan pengetahuan manusia, tetapi dapat diekspresikan melalui seni.

\section{Seni sebagai Anugerah Allah}

Seni adalah anugerah Allah yang diberikan kepada manusia untuk memuliakan Allah, sebab Allah telah menyelamatkan manusia dari kematian kekal akibat dosa. Manusia mewarisi daya kreasi seni dari Allah yang telah menciptakan manusia segambar dengan diri-Nya, sehingga dapat dikatakan bahwa seni adalah anugerah Allah bagi manusia. ${ }^{9}$ Dapatkah keindahan seni menyelamatkan manusia? Tentu seni seindah apapun tidak akan dapat menyelamatkan manusia, sebab hanya Allah saja yang dapat menyelamatkan manusia, yaitu melalui Kristus Anak-Nya yang Tunggal yang mati di kayu salib dan bangkit dari antara orang mati. Tetapi seni dapat menolong manusia mengkomunikasikan kebaikan, kebenaran dan keindahan Allah kepada setiap orang. ${ }^{10}$ Itu sebabnya seni dapat digunakan manusia untuk memuliakan Allah yang adalah "Seniman Sejati".

Luther dan para pengikutnya juga mendukung bahwa, seni adalah anugerah Allah bagi manusia. Bagi Luther, seni merupakan hadiah yang paling maksimal dari Tuhan untuk umatNya. Luther berkata, "saya mencintai musik (seni)... karena musik adalah hadiahnya Tuhan, bukan hadiah manusia". ${ }^{11}$ Luther mengatakan "Muximum, immo divinum donum" (musik adalah hadiah Tuhan yang sangat besar dari Allah untuk manusia), "Multitudo et magnitudo virtutis et bonitatis" (musik adalah hadiah yang memiliki kekuatan besar) dan "Salutaris et laeta cratura" (musik membawa sukacita keselamatan). ${ }^{12}$ Pernyataan ini menerangkan bahwa, pemikiran teologi Luther memasukkan musik (seni) sebagai bagian yang integral dalam kehidupan ibadah Kristen. Luther sangat mencintai teologi sebagai yang utama, tetapi Luther juga mencintai musik (seni) untuk memuliakan Allah.

Dengan keyakinan bahwa musik dan seni merupakan anugerah Allah bagi manusia, maka Luther dengan sangat berani mengklaim bahwa semua musik yang indah yang ada di dunia ini harus dipersembahkan untuk kemuliaan Tuhan. Bagi Luther, dunia dan setan tidak memerlukan yang indah-indah, yang indah adalah hak dari Tuhan. Luther mendorong banyak teman-temannya untuk membuat nyanyian yang indah untuk kebutuhan ibadah, selain ia juga menciptakan nyanyian-nyanyian bagi Tuhan. Abraham Kuyper juga mendukung bahwa, seni adalah anugerah Allah. Ia mengatakan bahwa seni adalah salah satu karunia Allah yang terkaya bagi umat manusia, ${ }^{13}$ maka wajar apabila seni telah digunakan manusia di sepanjang tradisi ibadahnya untuk memuliakan Allah. ${ }^{14}$ Fenomena seni yang tidak pernah jauh dari peribadatan

${ }^{9}$ Dalam pembahasan tentang seni khususnya musik, Martin Luther mengatakan bahwa musik merupakan hadiah yang terbesar Allah yang diberikan kepada manusia, dan musik itu membawa sukacita tanpa dosa, lihat: Hong Jong Soo, 교회 음악 개론 Pengantar Pelayanan Musik Gerejawi (Seoul: Presbyterian Theological Seminari South Korea Press, 1988).

${ }^{10}$ Albert L. Blackwell, The Sacred in Music (Louisville, Kentucky: The Lutterworth Press, 1999), 159-163.

${ }^{11}$ Hoong JongSoo, 교회음악개론 [Pengantar Musik Gereja] (Seoul: Presbyterian College and Theological Seminary Press, 1988), 29.

${ }^{12}$ Ibid., 30 dan 31.

${ }^{13}$ Pandangan Kuyper (1837-1920) dikutip dari David W. Hall \& Marvin Padgett (Ed.), Calvin dan Kebudayaan (Surabaya: Momentum, 2017), 51.

${ }^{14}$ Lihat: Andrew Wilson dan Dickson, The Story of Christian Music: From Gregorian Chant to Black Gospel an Ilustrated Guide to All The Major Tradisions of Music in Worship (Oxford: Lion Publishing plc, 1992); William J. Reynolds and Milburn Price, A Survey of Christian Hymnody (Illinois: Hope Publishing Company, 1978); Edward Foley, From Age to Age: How Christians Have Celebrated 
umat Tuhan juga dapat dilihat dalam tradisi ibadah di Perjanjian Lama ${ }^{15}$ maupun Perjanjian Baru. ${ }^{16}$ Tradisi tersebut terus berlangsung dan diwariskan oleh Bapa-bapa Gereja di masa Patristik, berlangsung turun-temurun dalam tradisi gereja hingga saat ini.

\section{Seni dalam Alkitab}

Di manakah letak seni dalam kehidupan umat Tuhan? Kita dapat menemukan pemakaian seni di masa awal sejarah umat Tuhan di dalam Alkitab. Di dalam Alkitab terdapat karya-karya seni yang sangat indah berupa nyanyian (mazmur), puisi, musik, maupun karyakarya arsitektur yang dipenuhi dengan beragam keindahan. Dalam Kitab Keluaran diungkapkan bagaimana Allah memerintahkan Musa untuk membuat tabut perjanjian. Tabut perjanjian berbentuk seperti sebuah peti artistik bernilai seni tinggi, karena dirancang oleh Allah sendiri. Allah mengajar Musa bagaimana membuat sebuah karya seni yang agung bagi Allah. Karya tersebut bukan merupakan karya seni biasa, sebab juga menjadi simbol kehadiran Allah (Kel. 25:8-10; Kel. 25:22). Allah berkata, "Dan di sanalah Aku akan bertemu dengan engkau dan dari atas tutup perdamaian itu, dari antara kedua kerub yang di atas tabut hukum itu, Aku akan berbicara dengan engkau tentang segala sesuatu yang akan Kuperintahkan kepadamu untuk disampaikan kepada orang Israel" (Kel. 25:22).

Karya seni yang luar biasa indahnya dalam Kitab Perjanjian Lama ditemukan dalam bentuk bangunan Bait Allah, yang menjadi simbol dari rumah Allah yang kudus, Allah berdiam di dalam bait-Nya yang kudus. ${ }^{17}$ Keindahan Bait Allah yang dibangun oleh Salomo atas perkenanan Allah tersebut merupakan bukti penerimaan seni sebagai elemen penting dalam ibadah masa Perjanjian Lama (1 Raj. 6). Bait Allah adalah sebuah bangunan yang didesain Allah sendiri, dengan bahan dan perhitungan yang khusus, mengekspresikan keindahan dan kebesaran Allah. Schaeffer mengatakan, "The temple, like the tabernacle, was not planned by man." ${ }^{18}$ Schaeffer menjelaskan bahwa Daud memberikan kepada Salomo seperti yang tertulis dalam kitab Tawarikh, "The pattern of all that he had by the Spirit" (1 Taw. 28:11-12). Tentang hal ini Firman Tuhan mengatakan, "All this, said David, have I been made to understand in writing from the hand of Jehovah, even all the works of this pattern," 1 Tawarikh 28:9. Tuhan mengajar manusia bagaimana membuat seni yang indah dan berkenan bagi Allah. Bangunan Bait Allah yang megah tersebut dibuat bukan untuk dikultuskan, melainkan mempermuliakan Allah. Benar yang dikatakan Hustad, "human art glorifies God,"19 seni hasil kreasi manusia mempermuliakan Allah. Seni yang hadir dalam rupa Bait Allah indah dan megah tersebut tidak hanya berbicara tentang keindahan saja, melainkan juga tentang kehadiran Allah di dalam BaitNya.

Karya seni lain dalam Perjanjian Lama hadir dalam bentuk nyanyian, nyanyian mazmur dan nyanyian canticle. Nyanyian mazmur tercatat lengkap dalam kitab Mazmur, sedangkan canticle adalah nyanyian lain selain mazmur yang juga terdapat di dalam Alkitab,

the Eucharist (Minnesota: Liturgical Press, 2008); Calvin R.Stapert, A New Song for an Old World Musical Thought in the Early Church (UK: Wm.B.Eermans Publishing, 2007); Donald J. Grout and Claude V. Palisca, A History of Western Music, Forth Edition (New York: Norton \& Company, Inc, 1988).

${ }^{15}$ Paul Westermeyerm, Tedeum: The Church and Music (Minneapolis: Fortress, 1998), 9-38.

${ }^{16}$ Westermeyerm, Tedeum, 39-58.

${ }^{17}$ Yesaya 6:1 mengkisahkan bagaimana Yesaya mendapat panggilan Allah, ia melihat Tuhan duduk di atas takhta yang tinggi dan menjulang, dan ujung jubah-Nya memenuhi Bait Suci.

${ }^{18}$ Francis A. Schaeffer, Art and the Bible (Illinois: InterVarsity Press, 2007), 25.

${ }^{19}$ Donald P. Hustad, Jubilate II: Church Music in Worship and Reneval (IL: Hope P.C, 1993), 6. 
seperti misalnya: Nyanyian Musa (Kel. 15; U1. 32), Nyanyian Yesaya (Yes. 26:9-21), Nyanyian Hana (1 Sam. 2:1-10), Nyanyian Yunus (Yun. 2:2-9), Nyanyian Habakuk (Hab. 3:2-19) dan Nyanyian Debora dalam Kitab Hakim-hakim. Foley, dalam bukunya, From Age to Age menjelaskan, bahwa nyanyian-nyanyian mazmur adalah salah satu bagian penting dari referensi nyanyian Bait Allah, dan beberapa mazmur khusus ditentukan untuk acara-acara khusus atau perayaan-perayaan festival. ${ }^{20}$ Disamping nyanyian Mazmur, bani Lewi juga menyanyikan varian canticle dan teks-teks puisi lain dari Alkitab. ${ }^{21}$

Mazmur merupakan karya nyanyian yang besar, yang tidak hanya mengekspresikan keindahan seni, tetapi juga menceritakan tentang perbuatan Allah yang besar di tengah umatNya. Buku nyanyian yang terdapat di dalam Perjanjian Lama, yang diperkirakan dikumpulkan pada saat pembuangan di Babilon. ${ }^{22}$ Dalam tulisan Reynold dikatakan bahwa, dalam kurun waktu 400 tahun antara kembalinya bangsa Israel dari pembuangan Babilon hingga masa Kristus, di Bait Allah telah dikembangkan suatu bentuk ibadah dan penyembahan. Kegiatan ibadah di Bait Allah terjadi sangat meriah dan megah, dipimpin oleh para imam dan paduan suara menyanyikan mazmur dan bagian dari Pentateukh dengan diiringi alat musik. Sementara di sinagoge, mereka menggunakan musik yang sangat sederhana dan biasanya mereka bernyanyi tanpa diiringi alat musik. ${ }^{23}$ Artinya pemakaian seni di dalam Bait Allah telah berlangsung selama ratusan tahun, bahkan di masa kini seni terus dikembangkan secara kreatif sebagai media pelayanan di dalam ibadah Kristen. Benar bahwa seni tidak pernah jauh dari tempat peribadatan di mana Allah bertemu dengan umat-Nya, sebab seni dapat dipakai menjadi sarana untuk memuliakan Allah.

Berdasarkan bukti-bukti dalam Kitab Mazmur dapat dipastikan bahwa, ada mazmurmazmur yang dinyanyikan untuk renungan pribadi, ibadah umum dan upacara-upacara khusus. Cara menyanyikan mazmur berdasarkan cara-cara yang telah ditentukan dan biasanya secara antifonal. ${ }^{24}$ Lagu untuk mazmur biasanya dipelajari secara lisan, mengingat tradisi tulis dalam sejarah musik mulai dikenal di abad ke-10. Dalam Kitab Tawarikh, dicatat bagaimana Daud di masa tuanya tetap melibatkan seni (musik) untuk pelayanan ibadah di Bait Allah (1 Taw 6:3133; 1 Taw 25:1, 6-8). Ia mengorganisasi para seniman, dan musisi-musisi profesional untuk keperluan ibadah. Ia memberikan penekanan bahwa pelayanan musik di Bait Allah harus ditangani secara khusus oleh orang khusus pula. Daud mempersembahkan seni yang terbaik di hadapan Allah melalui mengorganisasi para seniman yang profesional dibidangnya yang menjalankan tugasnya dengan baik dan menguduskan diri mereka bagi Allah.

Sejak masa gereja mula-mula, seni hadir dalam bentuk syair, puisi, tari, musik maupun nyanyian. Dalam Perjanjian Baru pun disebutkan, "Hendaklah perkataan Kristus diam dengan segala kekayaannya di antara kamu, sehingga kamu dengan segala hikmat mengajar dan menegur seorang akan yang lain dan sambil menyanyikan mazmur, dan puji-pujian dan nyanyian rohani, kamu mengucap syukur kepada Allah di dalam hatimu" (Kol. 3:16). Ayat ini memberikan gambaran bahwa, seni musik berperan memperkuat pengajaran firman untuk mendidik umat di dalam pertemuan jemaat.

\footnotetext{
${ }^{20}$ Edward Folley, Age to Age: How Christian Have Celebrated The Eucharist (Minnesota: Liturgical Press, Saint John's Abbey, 2008), 12.

${ }^{21}$ Folley, Age to Age, 12.

${ }^{22}$ William J. Reynolds \& Milburn Price, A Survey of Christian Hymnody (Carol Stram, Illinois: 1987), 1-2.

${ }^{23}$ William J. Reynolds and Milburn Price, A Survey of Christian Hymnody (Illinois: Hope Publishing Company, 1978), 1.

${ }^{24}$ William J. Reynolds \& Milburn Price, A Survey of Christian Hymnody (Carol Stram, Illinois: 1987), 2.
} 


\section{Seni dan Teologi Kristen}

Pandangan seorang teolog tentang seni akan memberikan pengaruh besar terhadap pandangan teologinya. Begbie mengatakan bahwa, pengaruh tersebut bukan hanya pada pandangan teologisnya saja, melainkan juga terhadap pandangan filosofisnya yang pada akhirnya tentu akan berpengaruh juga pada sikap maupun tindakannya. Dua tokoh penting yang mencoba mencari kejelasan tentang teologi Calvin dan warisannya atas seni yang didasarkan atas dua historiografi adalah Abraham Kuyper (1837-1920) dan Emile Doumergue (1844-1937). Penjelasan ini mengklarifikasi sikap para teolog Reformed yang selama ini sering dianggap sebagai anti terhadap seni.

Bagaimanakah hubungan seni dengan teologi Kristen? Seni adalah sebuah media yang dapat dipakai untuk memperkuat pesan teologi Kristen. Dalam hal ini seni tidak dihadirkan secara murni sebagai fine art (seni yang sejati atau seni demi dirinya sendiri), namun seni dipergunakan sebagai sarana untuk mengintegrasikan dan memperkuat pemaknaan pesan teologi. Tentu saja hal ini bukan tindakan semena-mena terhadap seni dan bukan merusak eksistensi dari seni itu sendiri, melainkan justru memperkaya fungsinya. Spirit ini akan mendorong munculnya karya-karya seni baru dari para seniman Kristen yang ditujukan untuk menyampaikan pesan yang dibawa oleh teologi Kristen kepada gereja dan masyarakat.

Klemen dari Alexandria (170-220), dari masa Patristik yang sering disebut sebagai "Bapak Teologi Yunani" berkata bahwa, nyanyian mempunyai kekuatan memotivasi diri sendiri dan juga orang lain. ${ }^{25}$ Oleh sebab itu, ia menggunakan seni khususnya musik dan nyanyian untuk membangun motivasi diri sendiri dan sesama dalam pengajaran firman. Klemen adalah seorang rektor Sekolah Teologi Alexandria yang sangat tertarik dengan nyanyian. Ia adalah orang pertama yang mengadakan pendekatan tentang kebenaran dan pengajaran Kristen melalui pemikiran Yunani dan spekulasi ajaran Gnostik. ${ }^{26}$ Nyanyian karyanya mengungkapkan usahanya untuk menggabungkan semangat puisi Yunani dengan teologi Kristen.

Di masa Abad Pertengahan, hubungan antara teologi dan seni tercermin pada pemakaian seni dalam peribadatan jemaat Kristen yang juga tidak lepas dari seni. Mereka menggunakan nyanyian poliponik seperti motet, misa, passion maupun nyanyian nyanyian rohani yang lain, termasuk juga nyanyian mazmur. Mereka menggunakan simbol-simbol bahkan patung di dalam liturginya, tetapi sayangnya terjadi dominasi-dominasi peran yang tidak pada tempatnya. Paradigma teologi yang tidak selaras dengan firman mengarahkan kegiatan peribadatan di masa itu hanya berfokus pada ekaristi dan elit gerejawi saja. Paradigma yang salah tersebut berimplikasi pada praktik hidup dan liturgi ibadah yang salah pula sebab lebih berakar pada tradisi daripada teologi yang alkitabiah.

Pada masa Renaisance, paradigma seni dan teologi menempati babak yang baru mereformasi paradigma lama Abad Pertengahan. Seni terutama musik dan nyanyian mengalami perkembangan lebih pesat, baik di gereja maupun di dalam masyarakat. Luther mendorong dan

\footnotetext{
${ }^{25}$ Calvin R.Stapert, A New Song for an Old World Musical Thought in the Early Church (UK: Wm.B.Eermans Publishing, 2007), 3.

${ }^{26}$ Salah satu sinkritisme yang dualistis pantheistis (lihat Bab 1 dan 3, Berkhof Enklaar, Sejarah Gereja (Jakarta: BPK Gunung Mulia, 1988), yang berusaha menghubungkan filsafat Barat dengan agama Timur, ialah gnostik, yakni ajaran tentang gnostis. Kata Gnostik berarti "pengetahuan," tetapi disini dimaksudkan suatu "hikmat tinggi" yang berahasia dan tersembunyi tentang asal dan tujuan hidup manusia. Pada zaman itu banyak orang terpelajar mangajar hikmat tinggi itu dengan giat, karena akalnya kurang dipuaskan oleh agama biasa yang mudah dipahami. Berita Injil dianggap terlampau sederhana, pada waktu itu jadi kurang digemari, sehingga gnostik merupakan tawaran menggiurkan bagi banyak orang. Mereka mulai menafsirkan Injil secara alegoris, dengan demikian "kebodohan salib" ditukarkannya dengan "hikmat dunia."
} 
mengupayakan terciptanya berbagai bentuk nyanyian sehingga jemaat dapat memuji Tuhan dengan bahasa yang dapat dimengerti. Syair nyanyian yang digubah oleh Luther dan para pengikutnya sangat dipengaruhi prinsip Teologi Firman, yaitu semboyan teologinya yang mengedepankan sola gracia, sola fide dan sola scriptura. Unsur teologis dari nyanyian ibadah Luther sangat dipentingkan, dan teks nyanyiannya mengekspresikan pesan teologi Alkitab, terdapat referensi ayat dalam setiap nyanyiannya. Ada yang merupakan kutipan langsung ayat Alkitab, parafrase ayat, atau narasi cerita yang mengimplikasikan pengajaran firman.

Calvin dan para pengikutnya juga terus mengembangkan nyanyian jemaat, terutama nyanyian mazmur yang diambil langsung dari Alkitab. ${ }^{27}$ Calvin sangat selektif terhadap pemakaian musik dan nyanyian bagi peribadatan maupun teologinya. Sikap Calvin yang mengakomodasi hanya nyanyian Mazmur dan menolak yang lainnya termasuk menghancurkan patung-patung dari dalam gereja sempat menuai kontroversi dari para teolog masa lampau maupun masa kini. Banyak pendapat bahwa Calvin dan Calvinisme merendahkan seni, hingga Voltaire mengatakan bahwa Calvinlah yang bertanggung jawab sehingga kota Jenewa menjadi keras karena menentang kenikmatan pertunjukan teater dan seni. ${ }^{28}$ Benarkah Calvin menolak seni bagi teologi? Nampaknya pandangan tersebut sangat subjektif, sebab dalam kenyataannya ada begitu banyak bukti yang menentang hal itu.

Kuyper, seorang teolog, pemikir dan Perdana Menteri Belanda tahun 1901-1905 mengatakan bahwa seni itu ada untuk meninggikan "Yang Mahaindah, dan Yang Maha Mulia dalam signifikansi-Nya yang kekal." ${ }^{29}$ Kuyper percaya seni berperan dalam mempercayai bahwa seni merupakan karunia Allah yang terkaya, sehingga dapat membantu mengenali manfaat dari agama yang sejati. Ia mendukung peran Calvinisme dalam bergerak dengan cara yang evolusioner menuju "tendensi kehidupan yang multiformitas". Kuyper berpendapat bahwa, berbeda dengan pencerahan dan rasionalisme, Calvinisme telah menghasilkan warisan yang kaya dalam bidang seni. ${ }^{30}$ Bagi Kuyper, Calvin bukanlah orang yang tidak tahu mengenai seni dan budaya, tetapi menurut Kuyper, Calvin ingin mengembangkan prinsip estetis yang baik, karena memang ada pandangan-pandangan Reformator yang menunjukkan penghargaan akan seni. Menurutnya, panggilan seorang seniman adalah untuk menemukan di dalam bentukbentuk natural itu tatanan dari hal-hal yang indah, diperkaya oleh pengetahuan yang lebih tinggi, menghasilkan suatu dunia yang lebih indah melampaui keindahan alam. ${ }^{31}$ Pengetahuan yang lebih tinggi (tertinggi) tersebut adalah Firman Tuhan, dengan demikian seni akan mengingatkan kepada kemuliaan sempurna yang akan datang.

Doumergue, seorang teolog Prancis berpendapat bahwa, "kaum Calvinis tidak hanya membebaskan seni tetapi membuatnya relevan bagi rakyat, dan menekankan kemungkinan psikologis dan rohani yang terkandung di dalamnya. ${ }^{32}$ Ia berpendapat bahwa wawasan dunia Reformed adalah penghasil seni, dengan menyebutkan tokohnya seperti Leon Wencelius dengan

${ }^{27}$ Lihat: William J. Reynolds and Milburn Price, A Survey of Christian Hymnody (Illinois: Hope Publishing Company, 1978).

${ }^{28}$ Voltaire dikutip dari Belden C. Lane, Revished by Beauty: The Surprising Legacy of Reformed Spirituality ( New York: Oxford University Press, 2011), 50.

${ }^{29}$ David W. Hall \& Marvin Padgett (Ed.), Calvin dan Kebudayaan (Surabaya: Momentum, 2017), 51. 177, 182-84].

${ }^{30}$ Abraham Kuyper and Doumergue, "Calvinisme and Art," 148, 151-52. [Edisi Indonesia:176-

${ }^{31}$ Kuyper and Doumergue, "Calvinisme and Art," [Edisi Indonesia:176-177, 182-84].

${ }^{32}$ David W. Hall \& Marvin Padgett (Ed.), Calvin dan Kebudayaan (Surabaya: Momentum, 2017), 53 
karya klasiknya yang berjudul "L'esthetique de Calvin". ${ }^{33}$ Dengan demikian bagi teolog Reformed, seni bukan hanya sebagai media saja tetapi juga sebagai mitra dalam memperkaya ekspresi dari teologi Kristen.

Reformed memberikan penekanan tentang seni khususnya tentang pentingnya nyanyian yang dapat menolong umat menyadari keberadaan Allah, bahkan menikmati Allah di dalam ibadahnya. ${ }^{34}$ Calvin bahkan berkata bahwa, "We know by experience that singing has great power and vigor to mode and inflame men's hearts to call upon and praise God with a more vehement and burning zeal." 35 Dari pernyataan tersebut dipahami bahwa, Calvin memandang nyanyian jemaat adalah penting dalam mewujudkan pengalaman bersama Tuhan secara subjektif, dan ia meyakini bahwa pengalaman melalui nyanyian tersebut memiliki kekuatan besar yang mampu membakar hati manusia untuk memuji dan memberikan kemuliaan kepada Allah Pencipta.

Dalam teologi, seni dapat difungsikan sebagai media yang dapat memperkuat dalam menanamkan nilai-nilai kebenaran Ilahi. Begbie, membuka bukunya dengan mengatakan, " $m y$ guiding conviction in this book is that music can serve to enrich and advance theology, extending our wisdom about God, God's relation to us and to the world etlarge." ${ }^{36}$ Keyakinan Begbie ini berakar dari hasil research dan pengalamannya selama bertahun-tahun melayani sebagai akademisi dan musisi. Ia yakin bahwa seni, khususnya musik dapat memperkaya dan memajukan, memperluas pengertian tentang Allah, dan juga relasi Allah pada kita dan kepada dunia luas. Dalam hal ini, seni selain sebagai media komunikasi dari sebuah pesan teologis, juga dapat digunakan sebagai sarana untuk berpikir secara lebih mendalam atau berpikir refleksif terhadap sebuah pesan teologis. Seni dapat hadir dalam bentuk drama, animasi, film, puisi atau syair, lukisan maupun nyanyian. Seni bukan hanya menyentuh akal budi manusia saja, tetapi juga dapat menyentuh hati dan jiwa manusia, sehingga lebih kuat pengaruhnya.

Prinsip teologi Kristen dapat diintegrasikan melalui atau ke dalam seni yang dapat dinikmati dan dimengerti oleh manusia. Prinsip teologi juga dapat diintegrasikan dalam berbagai mata kuliah yang disajikan di universitas Kristen. Apabila konsep tersebut diaplikasikan dalam konteks pendidikan Kristen, dan ketika prinsip-prinsip alkitabiah yang diintegrasikan tersebut meresap di dalamnya, maka sebuah paradigma sedang dibentuk mengarah kepada pikiran dan hati para peserta didik. Paradigma teologi Kristen ini akan memberikan pengaruh kepada cara pikir, bersikap maupun cara mahasiswa dalam mengambil tindakan-tindakan di sepanjang hidup mereka dalam masyarakat.

Gereja-gereja setelah masa Reformasi pun masih memiliki keyakinan bahwa, seni khususnya musik dapat memperkaya pengajaran tentang firman Tuhan. Hal tersebut dibuktikan dengan banyaknya gubahan nyanyian hymn yang berisi tentang pengajaran kristiani. Contohnya adalah Isaac Watts, seorang yang dikenal sebagai 'the father of English hymnody.' Ia berhasil mengintegrasikan pengajaran Kristus dalam Perjanjian Baru ke dalam nyanyian mazmur Perjanjian Lama, dan konsep ini merupakan sebuah pemikiran besar yang sangat brilliant.

${ }^{33}$ Emile Doumergue, L'art et le sentiment dans l'oeuvre de Calvin (Jenewa: Societe Genevoise d'Edition, 1992, dikutip dari: David W. Hall \& Marvin Padgett (Ed.), Calvin dan Kebudayaan (Surabaya: Momentum, 2017), 53.

${ }^{34}$ Lane menyebut pengalaman bersama Tuhan ini sebagai 'subjective experience of enjoying God, lihat: Belden C. Lane, Revished by Beauty: The Surprising Legacy of Reformed Spirituality (Oxford, New York: Oxford University Press, 2011), 78.

${ }^{35}$ John Calvin dalam Belden C. Lane, Revished by Beauty: The Surprising Legacy of Reformed Spirituality (Oxford, New York: Oxford University Press, 2011), 78.

${ }^{36}$ Jeremy S. Begbie, Theology, Music and Time (Cambridge: Cambridge University Press, 2007), 3 
Watts memiliki keyakinan besar bahwa, nyanyian dari gereja Perjanjian Baru harus dapat mengekspresikan Injil Perjanjian Baru, baik dalam versi penulisan mazmur maupun versi gubahan secara bebas dalam penulisan himne. ${ }^{37}$ Gerakan Watts telah mengubah bentuk dan karakater hymn pada masanya, baik dari segi sastra maupun spiritual. ${ }^{38}$ Dengan demikian, nyanyian Watts tersebut tidak hanya mengandung nilai seni musik saja, tetapi juga seni sastra.

Pada tahun 1719, ketika Issac Watts menulis himne (nyanyian jemaat) "Joy to the World," ia sungguh merenungkan bagaimana surga dan alam menyanyikan kemuliaan Tuhan. ${ }^{39}$ Watts memiliki keyakinan bahwa, seni dalam hal ini nyanyian himne selain memperkaya pengajaran Kristen, dan dapat digunakan untuk fungsi pemberitaan. Maka tidak berlebihan bila Begbie, membuka bukunya yang berjudul "Theology, Music and Time," dengan pernyataan, "My guiding conviction in this book is that music can serve to enrich and advance theology, extending our wisdom about God, God's relation to us and to the world etlarge." ${ }^{40}$ (Keyakinan saya yang terarah dalam buku ini adalah bahwa musik dapat dipakai untuk memperkaya dan memajukan, memperluas pengertian kita tentang Allah, relasi Allah pada kita dan kepada dunia luas). Pandangan ini juga diperkuat oleh Corbitt yang menulis buku berjudul "The Sound of the Harvest: Music's Mission in Church and Culture," yang mengatakan bahwa, "Music is theological; it talks about God and our relationship to him and our world, and answers one basic question: What is good life, and how does one attain it?"41 Ia juga mengatakan bahwa, "Music was preaching for Martin Luther; music was testimony to John Newton, the writer of "Amazing Grace". ${ }^{42}$ Musik merefleksikan tentang apakah iman Kristen dan teks yang ada di dalamnya yang berisi Firman Tuhan mengajar kita tentang Allah dan kebenaran-Nya.

\section{H. KESIMPULAN}

Seni memiliki hubungan yang sangat dekat dengan teologi dan peribadatan umat sejak masa awal. Relasi tersebut telah ada sejak masa Perjanjian Lama dalam peribadatan umat pilihan Allah. Kitab Mazmur mengekspresikan adanya relasi yang sangat dekat antara seni dan teologi pemazmur yang diwariskan secara turun-temurun hingga masa kini. Relasi tersebut diperkuat dalam Alkitab Perjanjian Baru, masa Patristik oleh Bapa-bapa Gereja, masa Abad Pertengahan oleh para teolog Middle Age, masa Reformasi oleh Luther dan Calvin serta pengikutnya, bahkan hingga masa sekarang yang secara mendasar tertuang dalam nyanyian pujian jemaat atau himnal.

Seni tidak hanya hadir dalam bentuk musik dan nyanyian saja, tetapi juga hadir dalam bentuk dekorasi ruang ibadah, arsitektur gereja, puisi dan sastra, drama, film, animasi dan lainnya. Seni yang membawa pesan teologi berfungsi untuk mengkomunikasikan dan memperkuat berita Firman Tuhan menyentuh hati, jiwa dan akal budi. Melalui seni, umat juga dapat menyampaikan rasa syukur dan pujian kepada Allah atas keselamatan yang telah diterimanya dari Allah. Seni juga dapat dipakai sebagai media pemberitaan Injil, studi tentang

\footnotetext{
${ }^{37}$ William J. Reynolds and Milburn Price, A Survey of Christian Hymnody (Illinois: Hope Publishing Company, 1978), 45.

${ }^{38}$ Reynolds, A Survey of Christian Hymnody, 51-52.

${ }^{39}$ J. Nathan Corbitt, The Sound of the Harvest: Music's Mission in Church and Culture (Grand Rapids, Michigan: Baker Books, 1998), 7.

${ }^{40}$ Jeremy S. Begbie, Theology, Music and Time (Cambridge: Cambridge University Press, 2007), 3.

${ }^{41}$ Corbitt, The Sound of the Harvest, 173.

${ }^{42}$ Corbitt, The Sound of the Harvest, 173.
} 
music in mission ${ }^{43}$ terus dikembangkan oleh para misionaris. Maka pada akhirnya dapat disimpulkan bahwa, seni dalam teologi Kristen dapat dipakai untuk memperkaya, menyegarkan dan memajukan serta memperluas pengertian kita tentang Allah, dan membangun relasi dengan Allah maupun dengan sesama.

\section{DAFTAR PUSTAKA}

Begbie, Jeremy S., Voicing Creation's Towards A Theology of The Arts. New York: T \& T. Clark, 2006.

Blackwell, Albert L. The Sacred in Music. Louisville, Kentucky: The Lutterworth Press, 1999.

Carritt, E. F. An Introduction to Aesthetics. London: Routledge, 1949.

Corbitt, J. Nathan, The Sound of the Harvest: Music's Mission in Church and Culture. Grand Rapids, Michigan: Baker Books, 1998.

Dickson, Andrew Wilson dan The Story of Christian Music: From Gregorian Chant to Black Gospel an Ilustrated Guide to All The Major Tradisions of Music in Worship. Oxford: Lion Publishing plc, 1992.

Enklaar, Berkhof, Sejarah Gereja. Jakarta: BPK Gunung Mulia, 1988.

Folley, Edward Age to Age: How Christian Have Celebrated The Eucharist. Minnesota: Liturgical Press, Saint John's Abbey, 2008.

Grout, Donald J. and Claude V. Palisca, A History of Western Music, Forth Edition. New York: Norton \& Company, Inc, 1988.

Hall, David W. \& Marvin Padgett (Ed.), Calvin dan Kebudayaan. Surabaya: Momentum, 2017.

Hunt, T.W. Music in Missions: Discipling Through Music. Nashville, Tennessee: Broadman Press, 1987.

Hustad, Donald P., Jubilate II: Church Music in Worship and Renewal (IL: Hope P.C. 1993).

Kuyper, Abraham and Doumergue, "Calvinisme and Art," [Edisi Indonesia:176-177, 182-84].

Kuyper, Abraham and Doumergue, "Calvinisme and Art," 148, 151-52. Edisi Indonesia:176177.

Orsini, Gian N. G., Benedetto Croce: Philosopher of Art and Literary Critic. Carbondale, III, 1961.

Lane, Belden C. Revished by Beauty: The Surprising Legacy of Reformed Spirituality. New York: Oxford University Press, 2011.

Reynolds, William J. and Milburn Price, A Survey of Christian Hymnody. Illinois: Hope Publishing Company, 1978.

Sugiharto, Bambang (Ed.), Untuk Apa Seni. Bandung: Matahari, 2013.

Soo, Hong Jong, 교회 음악 개론Pengantar Pelayanan Musik Gerejawi. Seoul: Presbyterian Theological Seminari South Korea Press, 1988.

Stapert, Calvin R., A New Song for an Old World Musical Thought in the Early Church. UK: Wm.B.Eermans Publishing, 2007.

Schaeffer, Francis A. Art and the Bible. Illinois: InterVarsity Press, 2007.

Westermeyerm, Paul Tedeum: The Church and Music. Minneapolis: Fortress, 1998.

\footnotetext{
${ }^{43}$ T.W. Hunt Music in Missions: Discipling Through Music (Nashville, Tennessee: Broadman Press, 1987).
} 